\title{
Uterine morphological changes induced by androgenic anabolic steroids
}

\author{
Eryck Holmes Alves da Silva*, Igor Rafael Praxedes de Sales², Lucas Norberto de Oliveira1, \\ Expedito Silva do Nascimento $\mathrm{Jr}^{1}$
}

\begin{abstract}
'Universidade Federal do Rio Grande do Norte (UFRN), Laboratory of Neuroanatomy, Department of Morphology, Natal, RN, Brazil 2Universidade Federal do Rio Grande do Norte (UFRN), Brain Institute, Natal, RN, Brazil
\end{abstract}

\begin{abstract}
Objectives: The aim of this study was to evaluate morphological alterations in uterus induced by the irrational use of Anabolic Androgenic Steroids (AAS), particularly Nandrolone decanoate (ND). Methods: This paper presents a retrospective study of scientific articles available in full and free electronic access, using the platform PubMed in Portuguese and English, that reviews the effects of isolated ND use on the uterus and reproductive parameters in experimental animals. Results: AAS besides causing various systemic effects, in certain experimental animals alters uterine histological patterns. Histological analysis of the uterus of rats treated with ND showed deleterious effects, i.e., vacuolization and edema of the endometrial stroma. Conclusions: Thus, we conclude that use of ND shows high reproductive risks and can cause both damages and irreversible physiological changes.
\end{abstract}

Keywords: nandrolone decanoate; reproduction; uterus; steroids.

\section{Introduction}

Androgenic Anabolic Steroids (AAS) are either synthetic or natural derivatives of the hormone testosterone, and thus have effects on multiple body tissues. ${ }^{1,2}$ In many countries such as Australia, Argentina, Canada, United Kingdom, United States and also in Brazil, ${ }^{3,4}$ control of these substances is maintained from marketing to prescription.

It is known that AAS act on androgen receptors expressed in virtually all cells of the body, and bring anabolic modulation as well as androgenic effects, ${ }^{3,4}$ such that no artificial synthetic steroid available on the market is able to trigger anabolic effects alone. ${ }^{5,6}$ This anabolic-androgenic relationship varies dependent on the substance used. ${ }^{7}$

There are a great variety of AAS and Nandrolone decanoate (ND) is one of the most used around the world. ${ }^{8}$ In Brazil it is marketed under the name Deca-Durabolin ${ }^{\circledR}$, and is considered one of the most popular steroids. ${ }^{9}$ Its active substance is nandrolone, which when compared to testosterone presents moderate androgenic potential and high anabolic activity. ${ }^{10,11}$

Administration of AAS brings adverse effects to multiple physiological systems. When applied in women, AAS promote menstrual irregularity, clitoral hypertrophy, changes in libido, and breast atrophy. . $^{1,3} 4$ These drugs also cause changes in the morphology of the uterus in experimental animals. Thus, in a study where ND administration was conducted in cynomolgus female monkeys (Macaca fascicularis), increases in uterine weight, endometrial thickness, and glandular area $^{12}$ have all resulted.

Considering the current lack of studies; and the often irrational use (on a large scale) of AAS by young people and adults; there is the need to bring from the literature such findings concerning injuries caused by the use of AAS correlated to the female reproductive system. This paper presents a review of the effects of isolated use of ND on the uterus and reproductive parameters of experimental animals.

Financial support: This study was supported by Coordenação de Aperfeiçoamento de Pessoal de Nível Superior (CAPES) and Universidade Federal do Rio Grande do Norte (UFRN).

Conflicts of interest: The authors declare no conflicts of interest.

Submitted: August 30, 2017.

Accepted: November 21, 2017.

Study carried out at Universidade Federal do Rio Grande do Norte (UFRN), Natal, RN, Brazil.

Copyright Silva et al. This is an Open Access article distributed under the terms of the Creative Commons Attribution License, which permits unrestricted use distribution, and reproduction in any medium, provided the original work is properly cited. 


\section{Methods}

A retrospective study was performed using scientific articles available in full and in free electronic access in the PubMed platform. We used the keywords: reproduction AND anabolic (550 articles), anabolic AND uterus (136 articles), and nandrolone decanoate AND reproduction (15 articles). After having selected the studies with the aim of answering the scientific question of the literature review, we selected 31 articles in Portuguese and English. The articles were analyzed for their goals, methods, results and conclusions.

\section{Results and discussion}

\section{General aspects of AAS}

Irrational use of AAS has focused the attention of both public health agencies and the scientific community. One may conceptualize all AAS as synthetic derivatives of testosterone, ${ }^{1}$ which are recommended in the medical clinic only under conditions involving acquired immunodeficiency syndrome (AIDS), kidney or liver disease, chronic obstructive pulmonary disease, postoperative recovery, cancer, burns,$^{13}$ sarcopenia ${ }^{14}$ and Turner's syndrome. ${ }^{15}$ However, AAS which are popularly known as anabolic agents, are improperly used by individuals in order to build muscle mass in a short period of time. ${ }^{16}$

Dosages of AAS administered may vary from 5 to 29 times the normal dose for physiological replacement of testosterone, and it is generally common to use cyclic schemes that range from approximately 5 to 10 weeks. $^{10}$

\section{Collateral effects of AAS in the body}

Effects generally associated with the illicit use of super-dosages of AAS include: "[...] liver toxicity, changes in the serum lipid profile, fluid retention, cardiac hypertrophy, hypogonadotropic hypogonadism, gynecomastia in men, hirsutism and menstrual irregularities in women, and behavioral changes". ${ }^{16}$ Other side effects may be observed exclusively in women users of AAS, such as, "[...] increased facial hair, deepening of the voice, clitoris enlargement and menstrual cycle disorders". ${ }^{17}$

Adverse effects may be temporary or permanent: appearing within a few weeks; (as an example: of reproductive function changed), or requiring up to several years; (as an example: of liver carcinoma). ${ }^{18}$ Studies also identify effects in women similar to those presented in men, such as, increased aggression, increased libido, acne, and hair loss. ${ }^{19}$

However, in terms of morphological and structural alterations, experiments with humans are not performed. Thus, studies in mammals bring to us that anabolic steroids when metabolized by the body are able to generate progestin. Progestin in the uterus leads to the proliferation of stromal cells, endometrial gland tortuosity, and myometrial hypertrophy. ${ }^{20}$

\section{Nandrolone decanoate}

From the great variety of AAS, we see that ND, commercially known as Deca-Durabolin ${ }^{\circledR}$ (Brazil) is considered the most popular steroid on the market (Figure 1). Studies using AAS have examined physiological and behavioral responses in men and women. However, the use frequency of such substances by women is less established in the literature than it is for men, and there is little information on the effects of ND on the reproduction of women from a morphological point of view. ${ }^{21}$

ND was introduced onto the market in 1962, being presented as an injectable anabolic preparation with extended activity of up to three weeks after intramuscular administration in humans (Figure 2). Its active ingredient is nandrolone, which has potential for both androgenic and anabolic activity. ${ }^{10,11}$

Users of ND administer exaggerated doses (typically $423.3 \mathrm{mg} /$ week) for an average of 9.7 weeks. Therapeutically, recommendations start at $50 \mathrm{mg}$ of ND every three weeks. In addition to improper application of supra-physiological doses, users of synthetic steroids often administer several different drugs simultaneously, increasing both the power of each anabolic steroid agent and their consequent androgenic effects. ${ }^{10}$

\section{Effect of ND in the female reproduction}

Few studies on any aspects of the effects of ND in the human or animal population have been performed in females.22 In recent years this panorama has not changed in the area of reproductive morphology. However, we have seen certain important and pioneering studies on morphological aspects relating to reproduction in mammals.

Despite the scarcity in the theme of feminine reproduction, important laboratory studies ${ }^{19-21,23}$ have helped us to understand that the synthetic steroid ND is able to cause changes in the estrous cycle, histopathological changes in the ovaries and the uterus, and is able to diminish female reproductive capacity, ${ }^{24}$ besides promoting vaginal atresia. ${ }^{25}$ 


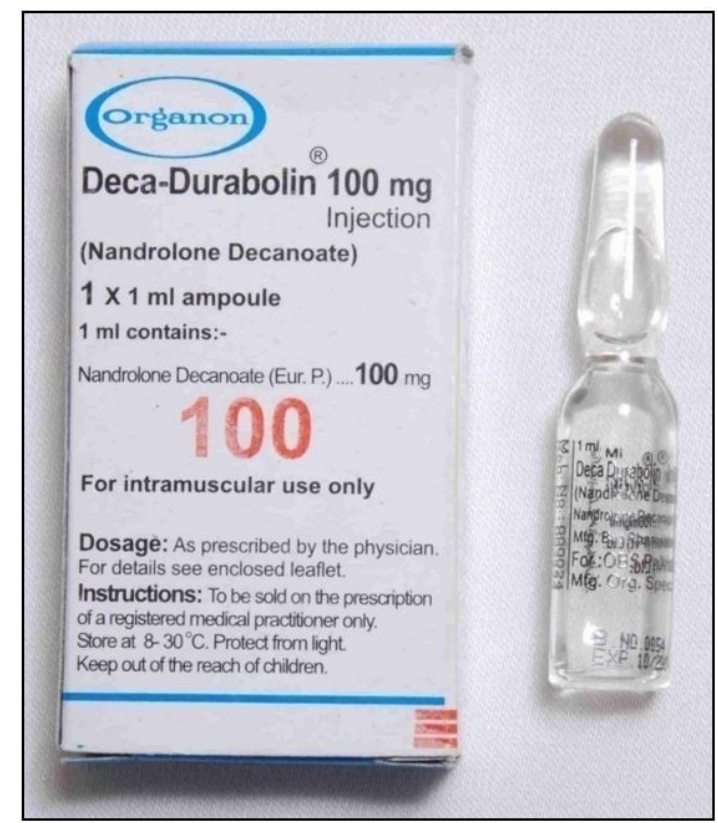

Figure 1. Packaging and ampule of Deca-Durabolin ${ }^{\circledR}$; manufacturer Organon (Taken from Gerez et al. ${ }^{21}$ - all rights reserved).

\begin{tabular}{|lr|}
\hline AAS & $\mathbf{K g}$ \\
\cline { 1 - 1 } Testosterone preparations & \\
Testosterone enanthate & 81.9 \\
Testosterone propionate & 32.1 \\
Testosterone isocaproate & 18.0 \\
\hline Testosterone decanoate & 5.5 \\
\hline Testosterone cypionate & 5.2 \\
Testosterone phenylpropionate & 1.5 \\
Testosterone (unesterified) & 1.3 \\
Total & 145.5 \\
Metandienone & 34.3 \\
\hline Nandrolone & 26.6 \\
\hline Trenbolone & 15.9 \\
Stanozolol & 10.3 \\
Oralturinabol & 10.0 \\
Boldenone & 8.9 \\
Drostanolone & 4.7 \\
Oxandrolone & 1.2 \\
Oxymetholone & 1.2 \\
Methenolone & 0.3 \\
Methyldrostanolone & 0.3 \\
Total & 259.3 \\
\hline
\end{tabular}

Figure 2. AAS constitute $87 \%$ of illegal performance enhancing drugs as confiscated by customs, or on the German black market in 2010-2013; more than half are preparations of testosterone (Taken from Nieschlag and Vorona ${ }^{28}$ - all rights reserved).

In feminine physiology, supra-physiological doses of steroids promote adverse effects in the organism. The most commonly cited in studies with humans are menstrual irregularities, enlargement of the clitoris, deepening of the voice, and hair growth..$^{1,4}$ In studies with primarily female rodents ND increases the number of atresial follicles ${ }^{19}$ and induces a reduction in the number of ovarian oocytes. ${ }^{26}$

ND also causes certain changes in the uterine morphology of experimental animals; certain studies bring us relevant data about these changes. One of the first relations to uterine morphology with administration of ND in cynomolgus female monkeys revealed increases in uterine weight, endometrial thickness and glandular area, as well as adenomyosis-like alterations and a high incidence of mucometra, which brings greater chances of infertility. ${ }^{12}$ 
In addition, endometrial vacuolization and edema stromal have been observed in rats treated with ND. The use of ND can be associated with adverse effects on reproduction, associated with physiological and morphological characteristics, and even behavioral changes. ${ }^{27}$

If changes in the reproductive system, such as dysmenorrhea, secondary amenorrhea with anovulation, and reduced breast size, due to the suppression of hypothalamic-pituitary-gonadal functions are attributed to the abuse of ND, they should also, being caused by AAS, be reversible. It might take weeks or months before recovery. In certain cases, it has been reported that after termination of administrations in women, approximately 20 months passed until concentrations of testosterone in the blood fell back to normal levels. Regarding possibly irreversible side effects in women, such as clitoris enlargement, well-documented cases or studies were not available. ${ }^{28}$

\section{Anatomical changes in the uterus}

ND causes various effects in the organism, yet in experimental animals, it also causes various changes in the morphology of the uterus. Certain studies bring us relevant data concerning such changes, but there are few studies specifically related to changes in the uterus and their correlations. The administration of ND in female rats has been shown to cause increases in myometrium thickness, even as the endometrium atrophied. Androgenic receptors expressed by smooth muscle cells may well be involved in uterine hypertrophy and the proliferation of ND's effects. ${ }^{29}$

Researchers have shown that ND whether associated or not with other substances harmful to the body, and physical exertion results in histomorphometric changes in the uterus of female adult rats (Figure 3). The study presented micrometer sections of uterine epithelium, endometrium, myometrium and the perimeter as assessed in the proximal, middle and

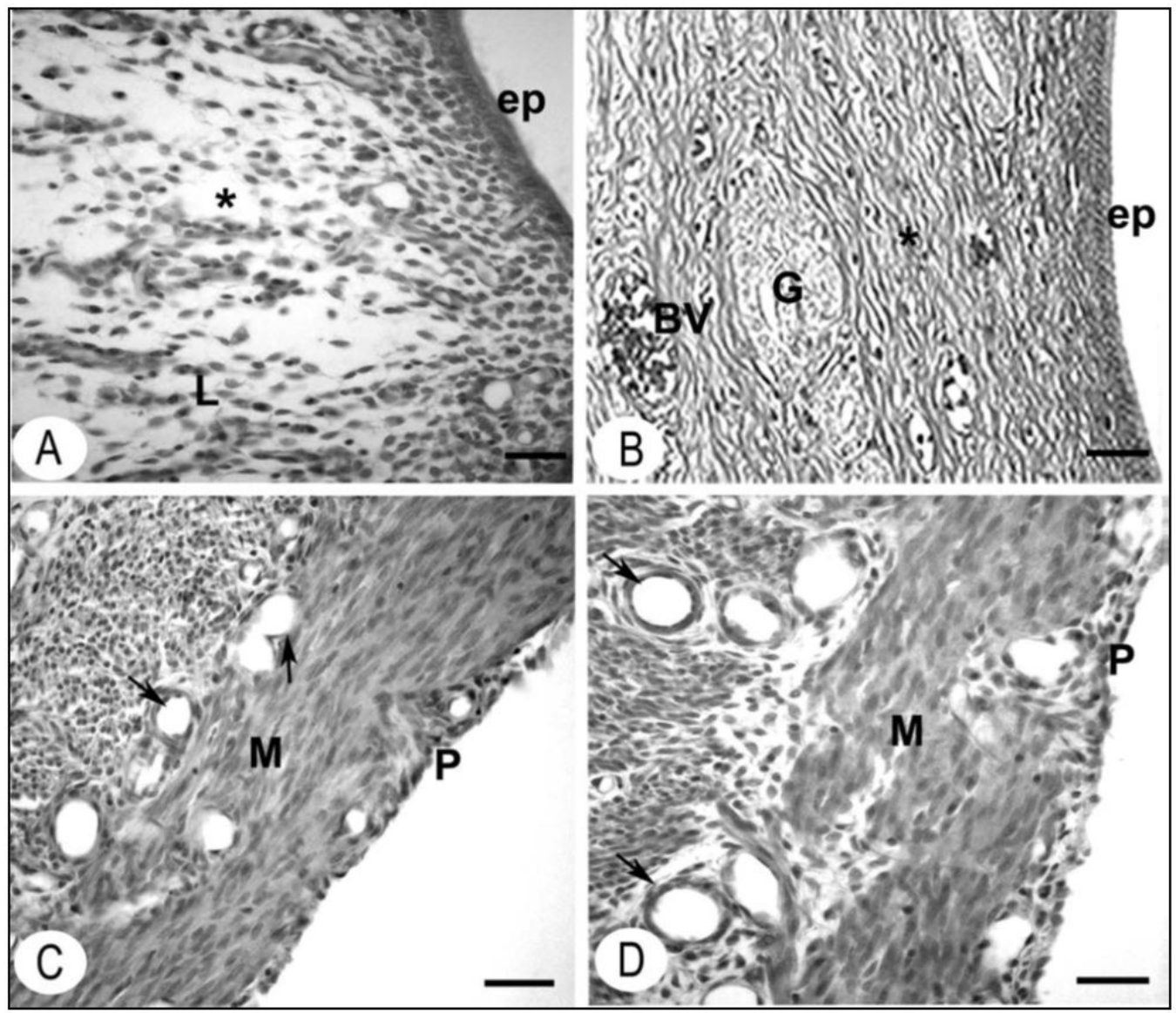

Figure 3. Morphology of uterine layer in rats treated with ND and the control group, subject or not to physical effort. In (A), observe the slightly edematous stroma $\left({ }^{*}\right)$ with scattered leucocytes. The ND + physical effort group (B), fibrous stroma (*) with narrow glands $(\mathrm{G})$ and the prominent blood vessels (BV). The muscle layer inside the myometrium blood vessels (arrows) of rats ND + physical effort (C), showed reductions in both number and diameters, in contrast with (ND + without physical effort) rats (D); PE: uterine epithelium, L: leukocytes, M: myometrium, P: perimeter. Mallory's trichrome (Taken from Chuffa et al. ${ }^{19}$ - all rights reserved). 
distal portions of the uterus. The thickness of the epithelium was measured at the surface of the endometrium and the thickness of the stroma was obtained by screening images with a cursor repeating measurements of both basal and functional layers. The values were taken to be the total uterine area and transversal section. ${ }^{19}$

\section{Histological changes in the uterus}

In certain experimental animals, such as mammals, rodents, and monkeys, AAS causes various systemic effects and changes to histological patterns in the uterus. Studies conducted administering ND in cynomolgus female monkeys resulted in increased endometrial thickness and glandular area, as well as a high incidence of uterine mucosa. ${ }^{12}$ In another study, endometrial vacuolization and stromal edema were observed (Figure 4A) in rats treated with ND. ${ }^{27}$ These data help to further elucidate the effects of ND on morphological patterns of the uterus in experimental animals.

The disappearance of granulocytes and eosinophils from the endometrium of the uterus of animals treated with ND (as observed) was not reported in previous studies. However, it is well known that the infiltration of multiple immune system cells to the uterus varies with the estrous cycle, which in turn is regulated by plasma levels of steroids, hormones, estrogen. ${ }^{30}$

Many evidences suggest that eosinophils play an important role in cyclic endometrium regulation. In humans an influx of eosinophils in the endometrium occurs immediately before and during menstruation and there is also a pronounced accumulation of leukocytes in the endometrium during the pre-implantation and early pregnancy. Eosinophils in the endometrium express receptors that are regulated by various chemokines, and are also regulated by estrogen. ${ }^{31}$

After analysis of a study on the histological structure of the uterus, it was found that in all rats the endometrium is affected by steroidal treatments. However, the myometrium and perimeter in these females presented morphological patterns similar to those observed in non-androgenized females. In the control group, the luminal epithelium of the simple columnar type was characterized as rectilinear in appearance (Figure 5A). Fibro-cellular stroma leukocyte counts were dispersed, chiefly in the region underlying the epithelium, with glands of reduced lumen. The uterine cavity was devoid of secretion. In each androgenized group, the endometrial structure was similar. In the groups treated with ND, the luminal epithelium presented fibroelastoma (Figure 5B), simple columnar cubic type coating, and secretions in the interior of the uterine cavity. The endometrial stroma, with an edemal aspect presented disperse tissue leukocytes, and hemorrhaging areas were observed in the interiors of the fibroelastomas (Figure 5B). ${ }^{20}$

In another study it was possible to corroborate data where in their work with adult rats and administration of ND, certain histomorphological changes in the uterus were noted. In the control group (Figure 6A), the epithelial cells of the uterine lumen were tall and cylindrical, with nuclei located on the same level. The endometrial stroma was relatively thin, having a loose aspect with the presence of lymphocytes scattered in the tissue. Certain tortuous glands were exposed with the presence of a few sub-nuclear vacuoles while others showed tubular appearance. The females of the group treated with ND presented a different uterine histology from the control group. The more evident characteristic morphology in the uterus of the androgenized females (Figure 6B) was the presence of vacuolated epithelium in the

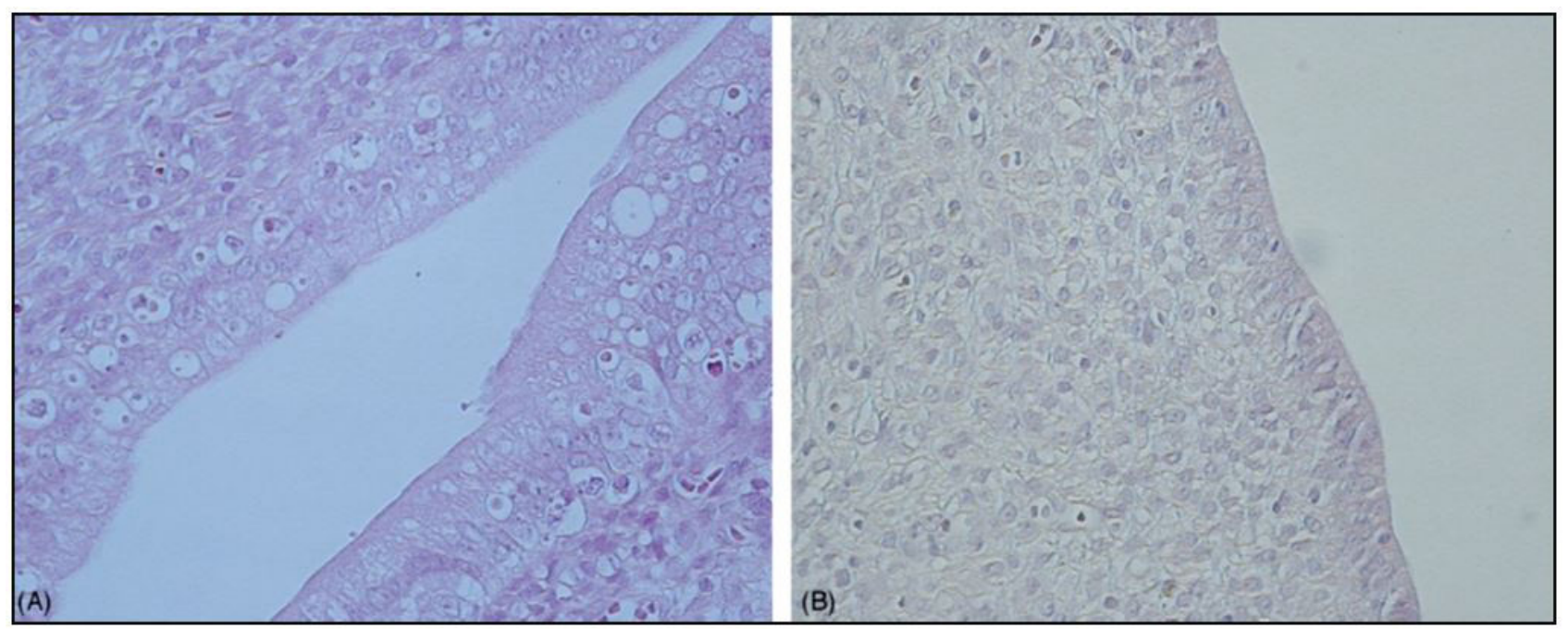

Figure 4. Vacuolization of the endometrium epithelium in rat uterus treated with ND (A), and the control group (B). HE staining (Taken from Mobini Far et al. ${ }^{27}$ - all rights reserved). 


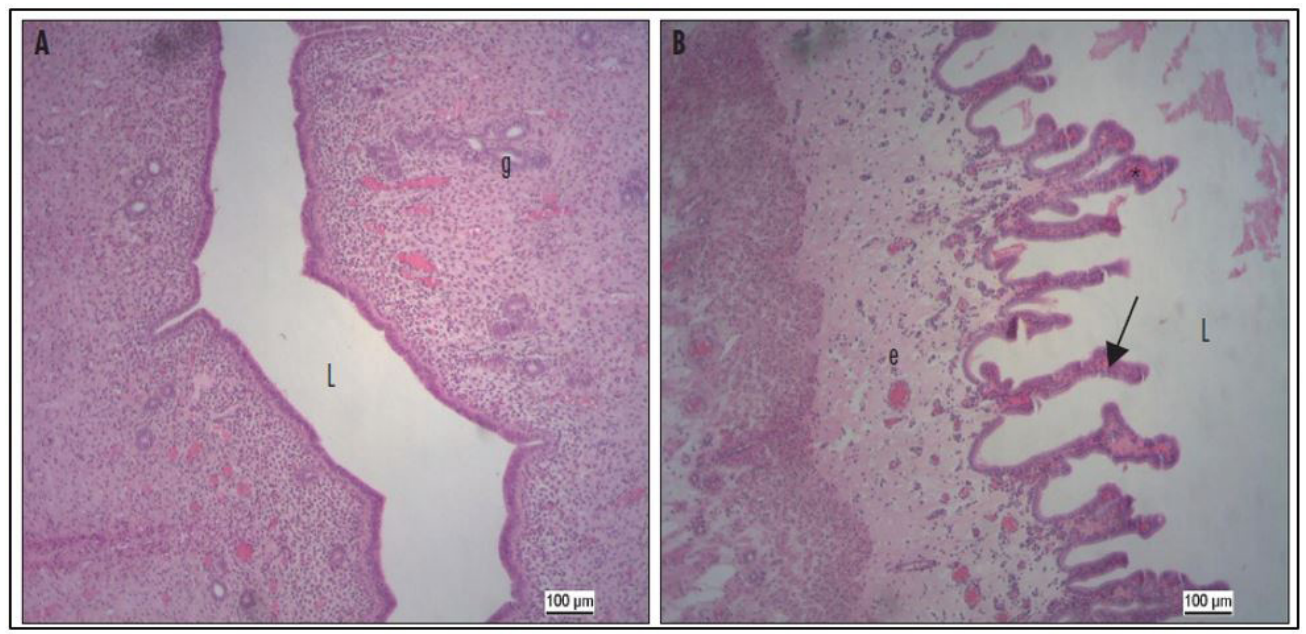

Figure 5. Rat endometrium in the control group (A), and treated with ND (B). In the androgenized groups note the appearance of fibroelastoma in the epithelium of the lumen (arrows), edematous stroma (e), and secretion in the uterine lumen (L). Hemorrhagic areas $\left.{ }^{*}\right)$ are shown on the inside of the papillaries or the underlying stroma. The glands (g) exhibit luminal secretion in the groups treated with steroids. In the control group (A), the luminal coating epithelium presents a rectilinear aspect and there is an absence of secretion in the light (L). The tubular glands (g) do not exhibit secretory activity. HE staining (Taken from Camargo et al. ${ }^{20}$ - all rights reserved).

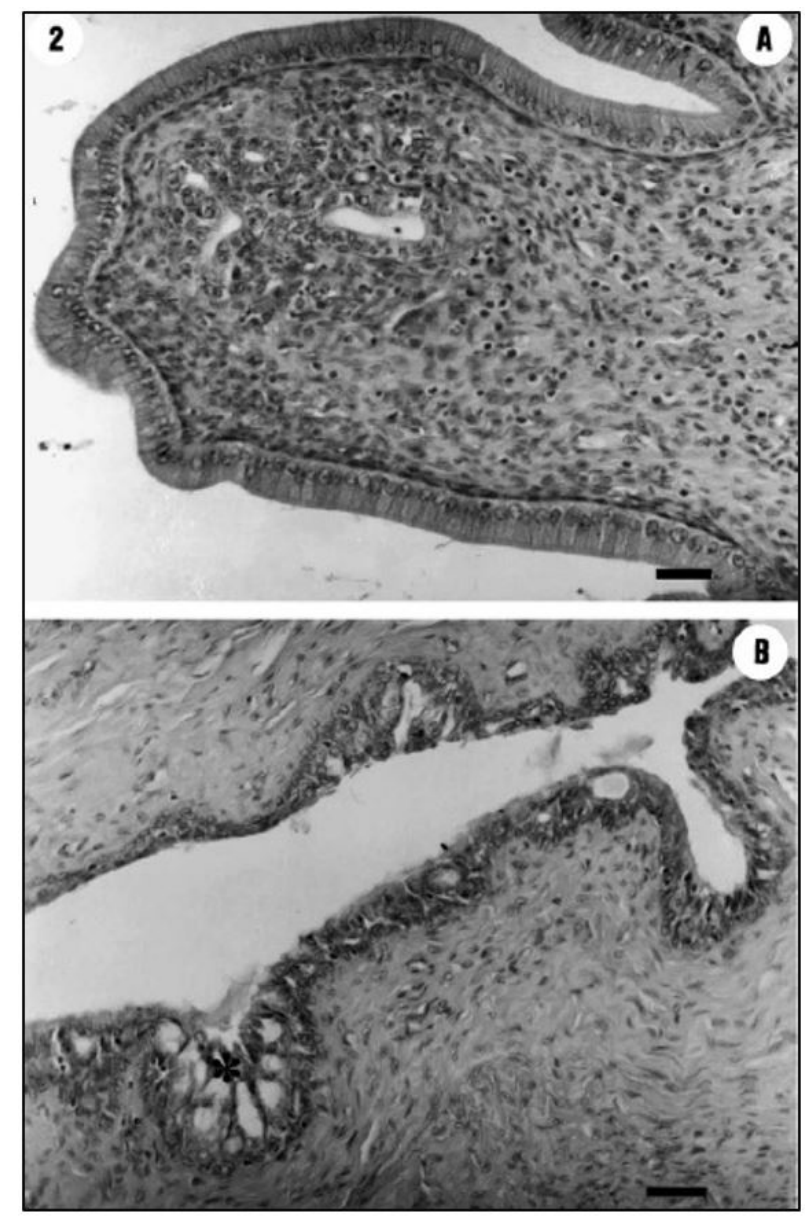

Figure 6. Photomicrographs of rat uterus. Note columnar epithelium and stroma with loose aspect in the control group (A), and vacuolated epithelium $\left(^{*}\right)$, and dense aspect stroma in the group treated with ND (B). HE staining (Taken from Gerez et al. ${ }^{21}$ - all rights reserved). 
lining of the lumen and stroma with a dense appearance. The morphology of the uterine lumen coating ranged from simple cylindrical or pseudo-stratified epithelium, to a stratified appearance. The glands showed a tubular aspect, and pseudo-stratified nuclei with mitotic activity, indicating the morphological characteristics of the proliferative phase. ${ }^{21}$

\section{Final considerations}

From the literature search, we note that the scarcity of studies and publications concerning the effects of AAS (mainly ND) on the uterus morphology. Discrepancies in the results obtained in the different studies analyzed are due to different species and strains, experiments, and the doses used in the procedures. Although abusive use of AAS is a health public problem both in men and women, there are few studies published about the effects of AAS on uterine pathophysiology and morphology. Histological analyses of the uterus of rats treated with ND showed deleterious effects related to vacuolization and edema of the endometrial stroma. Thus, we conclude that irrational and excessive use of these substances can lead to irreversible changes and possible infertility.

\section{References}

1. Hoffman JR, Ratamess NA. Medical issues associated with anabolic steroid use: are they exaggerated? J Sports Sci Med. 2006;5(2):18293. PMid:24259990.

2. Fragkaki A, Angelis Y, Koupparis M, Tsantili-Kakoulidou A, Kokotos G, Georgakopoulos C. Structural characteristics of anabolic androgenic steroids contributing to binding to the androgen receptor and to their anabolic and androgenic activities. Steroids. 2009;74(2):172-97. PMid:19028512. http://dx.doi.org/10.1016/j.steroids.2008.10.016.

3. Bahrke M, Yesalis C. Abuse of anabolic androgenic steroids and related substances in sport and exercise. Curr Opin Pharmacol. 2004;4(6):614-20. PMid:15525553. http://dx.doi.org/10.1016/j.coph.2004.05.006.

4. Kicman A. Pharmacology of anabolic steroids. Br J Pharmacol. 2008;154(3):502-21. PMid:18500378. http://dx.doi.org/10.1038/ bjp.2008.165.

5. Clarkson P, Thompson H. Drugs and Sport. Sports Med. 1997;24(6):366-84. PMid:9421862. http://dx.doi. org/10.2165/00007256-199724060-00003.

6. Lise MLZ, Gama e Silva TS, Ferigolo M, Barros HM. Gama e Silva TS da, Ferigolo M, Barros HMT. O abuso de esteroides anabólicoandrogênicos em atletismo. Rev Assoc Med Bras. 1999;45(4):364-70. PMid:10752246.

7. Cunha TS, Cunha NS, Moura MJCS, Marcondes FK. Esteroides anabólicos androgênicos e sua relação com a prática desportiva. Rev Bras Cienc Farm. 2004;40(2):165-79. http://dx.doi.org/10.1590/S1516-93322004000200005.

8. Kutscher E, Lund B, Perry P. Anabolic steroids. Sports Med. 2002;32(5):285-96. PMid:11929356. http://dx.doi. org/10.2165/00007256-200232050-00001.

9. Ichihara I, Kawamura H, Nakano T, Pelliniemi L. Ultrastructural, morphometric, and hormonal analysis of the effets of testosterone treatment on leydig cells and other interstitial cells in young adult rats. Annals of Anatomy - Anat Anz. 2001;183(5):413-26. http:// dx.doi.org/10.1016/S0940-9602(01)80196-5.

10. Perry P, Lund B, Deninger M, Kutscher E, Schneider J. Anabolic steroid use in weightlifters and bodybuilders. Clin J Sport Med. 2005;15(5):326-30. PMid:16162991. http://dx.doi.org/10.1097/01.jsm.0000180872.22426.bb.

11. Silva P, Machado Júnior L, Figueiredo V, Cioffi A, Prestes M, Czepielewski M. Prevalência do uso de agentes anabólicos em praticantes de musculação de Porto Alegre. Arq Bras Endocrinol Metabol. 2007;51(1):104-10. PMid:17435863. http://dx.doi. org/10.1590/S0004-27302007000100017.

12. Obasanjo I, Cline J, Schmotzer S, Weaver D. Nandrolone decanoate causes pathologic changes in the uterus of surgically postmenopausal female cynomolgus macaques. Menopause. 1998;3(5):163-8. PMid:9774762. http://dx.doi.org/10.1097/00042192-199805030-00006.

13. Basaria S, Wahlstrom J, Dobs A. Anabolic-androgenic steroid therapy in the treatment of chronic diseases. J Clin Endocrinol Metab. 2001;86(11):5108-17. PMid:11701661. http://dx.doi.org/10.1210/jcem.86.11.7983.

14. Silva T, Frisoli Jr A, Pinheiro M, Szejnfeld V. Sarcopenia associada ao envelhecimento: aspectos etiológicos e opções terapêuticas. Rev Bras Reumatol. 2006;46(6) http://dx.doi.org/10.1590/S0482-50042006000600006.

15. Rosenfeld R, France J, Attie K, Brasel J, Burstein S, Cara J, et al. Six-year results of a randomized, prospective trial of human growth hormone and oxandrolone in Turner syndrome. J Pediatr. 1992;121(1):49-55. PMid:1625092. http://dx.doi.org/10.1016/ S0022-3476(05)82540-5.

16. Camargo ICC, Gênova TC, Machado MCP, Frei F, Mesquita SFP. Administração experimental de esteróide anabólico androgênico e álcool causa alterações histológicas e morfométricas nos ovários e útero de ratas adultas. Biosci J. 2011;27(4):656-65.

17. Ferreira NAF, Sá SGV, Aleixo IB, Paiva AMR. Estudo dos efeitos provocados pelo uso do anabolizante estanozolol. Braz J Surg Clin Res. 2014;7(3):17-23.

18. Hickson R, Ball K, Falduto M. Adverse effects of anabolic steroids. Med Toxicol. 1989;4(4):254-71. PMid:2671596. http://dx.doi. org/10.1007/BF03259912. 
19. Chuffa LA, Souza R, Frei F, Mesquita SFP, Camargo I. Nandrolone decanoate and physical effort: histological and morphometrical assessment in adult rat uterus. Anat Rec. 2010;294(2):335-41. PMid:21235008. http://dx.doi.org/10.1002/ar.21314.

20. Camargo I, Gaspar A, Frei F, Mesquita S. Efeitos dos esteroides anabólicos androgênicos sobre o útero e parâmetros reprodutivos de ratas adultas. Rev Bras Ginecol Obstet. 2009;31(9):453-60. PMid:19876577. http://dx.doi.org/10.1590/S0100-72032009000900006.

21. Gerez J, Frei F, Camargo I. Histological assessment of ovaries and uterus of rats subjected to nandrolone decanoate treatment. Contraception. 2005;72(1):77-80. PMid:15964297. http://dx.doi.org/10.1016/j.contraception.2005.02.001.

22. Clark A, Costine B, Jones B, Kelton-Rehkopf M, Meerts S, Nutbrown-Greene L, et al. Sex- and age-specific effects of anabolic androgenic steroids on reproductive behaviors and on GABAergic transmission in neuroendocrine control regions. Brain Res. 2006;1126(1):122-38. PMid:17010954. http://dx.doi.org/10.1016/j.brainres.2006.08.081.

23. Camargo I, Leite G, Pinto T, Ribeiro-Paes J. Histopathologycal findings in the ovaries and uterus of albino female rats promoted by co-administration of synthetic steroids and nicotine. Exp Toxicol Pathol. 2014;66(4):195-202. PMid:24556002. http://dx.doi. org/10.1016/j.etp.2014.01.005.

24. Belardin L, Simão V, Leite G, Chuffa L, Camargo I. Dose-dependent effects and reversibility of the injuries caused by nandrolone decanoate in uterine tissue and fertility of rats. Birth Defects Res B Dev Reprod Toxicol. 2014;101(2):168-77. PMid:24753332. http://dx.doi.org/10.1002/bdrb.21104.

25. Wolf C, Hotchkiss A, Ostby JS, LeBlanc GA, Gray Jr LE. Effects of prenatal testosterone propionate on the sexual development of male and female rats: a dose-response study. Toxicol Sci. 2002;65(1):71-86. PMid:11752687. http://dx.doi.org/10.1093/ toxsci/65.1.71.

26. Karbalay-Doust S, Noorafshan A. Stereological estimation of ovarian oocyte volume, surface area and number: application on mice treated with nandrolone decanoate. Folia Histochem Cytobiol. 2012;50(2):275-9. PMid:22763965. http://dx.doi.org/10.5603/ FHC.2012.0037.

27. Mobini Far H, Ågren G, Lindqvist A, Marmendal M, Fahlke C, Thiblin I. Administration of the anabolic androgenic steroid nandrolone decanoate to female rats causes alterations in the morphology of their uterus and a reduction in reproductive capacity. Eur J Obstet Gynecol Reprod Biol. 2007;131(2):189-97. PMid:16982131. http://dx.doi.org/10.1016/j.ejogrb.2006.07.037.

28. Nieschlag E, Vorona E. MECHANISMS IN ENDOCRINOLOGY: medical consequences of doping with anabolic androgenic steroids: effects on reproductive functions. Eur J Endocrinol. 2015;173(2):R47-58. PMid:25805894. http://dx.doi.org/10.1530/EJE-15-0080.

29. Mertens H, Heineman M, Koudstaal J, Theunissen P, Evers J. Androgen receptor content in human endometrium. Eur J Obstet Gynecol Reprod Biol. 1996;70(1):11-3. PMid:9031911. http://dx.doi.org/10.1016/S0301-2115(96)02567-5.

30. Kaeoket K, Persson E, Dalin A. The sow endometrium at different stages of the oestrous cycle: studies on morphological changes and infiltration by cells of the immune system. Anim Reprod Sci. 2001;65(1-2):95-114. PMid:11182512. http://dx.doi.org/10.1016/ S0378-4320(00)00211-6.

31. Jones R, Hannan N, Kaitu'u T, Zhang J, Salamonsen L. Identification of chemokines important for leukocyte recruitment to the human endometrium at the times of embryo implantation and menstruation. J Clin Endocrinol Metab. 2004;89(12):6155-67. PMid:15579772. http://dx.doi.org/10.1210/jc.2004-0507.

\section{*Correspondence}

Eryck Holmes Alves da Silva

Universidade Federal do Rio Grande do Norte (UFRN), Biosciences Center, Laboratory of Neuroanatomy, Department of Morphology Campus Universitário BR 101, S/N, Lagoa Nova

CEP 59072-970, Natal, RN, Brazil

Tel.: +55 (83) 99935-9183

E-mail: eryck_holmes@hotmail.com

\section{Author information}

EHAS - Speech Therapist, Master graduate student; UFRN. IRPS - Master in Pharmacology; PhD student; UFRN. LNO - Biomedic; Master graduate student; UFRN. ESN Jr - PhD in Psychobiology and Adjunct professor; UFRN.

\section{Author contribution}

All authors contributed equally in this study. Study concept and preparation of data bank: EHAS and LNO. Drafting of the manuscript: EHAS, LNO, IRPS and ESNJ. Critical revision: IRPS and ESNJ. Study supervision: ESNJ. 